\title{
CONSERVAREA IN SITU A AGROBIODIVERSITĂȚII VEGETALE - FACTOR DE REUȘITĂ ÎN PROMOVAREA AGRICULTURII DURABILE
}

\author{
Ganea Anatolie \\ Institutul de Genetică, Fiziologie și Protecție a Plantelor, Chișinău, Republica Moldova \\ e-mail: anatolie.ganea@igfpp.md
}

\begin{abstract}
The article gives brief information on inventorying of some crop wild relatives in the forest ecosystems of different soil-climatic zones of Republic of Moldova, and collection of accessions of the local forms of cultivated plants on farms. It was found that natural populations of 5 pilot species - wild cherry, wild pear, cornelian cherry, wild apple and hazelnut are degrading under the influence of environmental stresses. It is noted that the range of social-economic and political factors of the past 60-70 years has led to significant genetic erosion of the local gene pool of agricultural crops. Elaboration of the effective methods for in situ conservation of agrobiodiversity will facilitate the greening of agricultural production and introduction of the elements of sustainable agriculture.
\end{abstract}

Key words: agrobiodiversitate, conservarea in situ, rude sălbatice ale plantelor cultivate, forme locale de culturi agricole, agricultura durabilă.

\section{Introducere}

Rezoluția 70/1, adoptată de către Adunarea Generală a ONU la 25 septembrie 2015 a trasat un plan colectiv în vederea obținerii păcii și stării prospere pentru toată populaţia Terrei [1]. Cele 17 obiective de dezvoltare durabilă au ca sarcină depășirea provocărilor globale impuse de sărăcie, inegalităti, schimbările climatice, degradarea mediului, problemele păcii și dreptății. Evoluarea civilizației umane, mai ales, în ultimii 50-60 de ani, ne-a demonstrat elocvent că biodiversitatea este esențială pentru dezvoltarea și bunăstarea ființei umane și reprezintă, de fapt, fundamentul prosperității economice. După cum reiese din studiul efectuat [2], mai mult de jumătate din PIB-ul mondial, echivalentul a aproximativ 44 trilioane de dolari americani, este moderat sau e foarte dependent de natură. Mai mult de 70\% dintre persoanele care trăiesc în sărăcie depind totalmente sau parțial de resursele naturale pentru a-și câștiga existența. Natura este o sursă principală pentru fabricarea multor medicamente utilizate în medicina modernă [3].

Biodiversitatea agricolă este definită ca "varietatea și variabilitatea animalelor, plantelor și microorganizmelor care sunt folosite direct de indirect pentru alimentație și agricultură. Aceasta a inclus diversitatea resurselor genetice (varietăților, raselor) și speciilor utilizate pentru alimentație, furaje, fibre, combustibil și produse farmaceutice. De asemenea termenul include diversitatea speciilor necultivate care favorizează producția agricolă (microorganismele din sol, prădătorii, polenizatorii) și cei din mediul mai larg care susțin agro-ecosistemele [4].

Pentru a fi considerată durabilă, agricultura trebuie să integreze interesele sociale, de mediu și economice. Obiectivele agriculturii durabile sunt pentru a pune la dispoziție suficientă hrană populației, pentru a scoate comunitățile din sărăcie și pentru a oferi o calitate a vieții sporită, dar și pentru a utiliza metode agricole care promovează sănătatea solului și reduc dependența de combustibilul fosil. Dezvoltarea perpetuă a sectorului agricol în scenariul agriculturii durabile nu poate fi realizată fără existența unei eficiente interacțiuni cu elementele agrobiodiversităţii.

FAO a definit sistemele alimentare durabile ca "un sistem alimentar care livrează securitatea alimentară și nutriția pentru toți în așa fel, încât bazele economice, sociale și de mediu care generează securitatea alimentară și nutriția generațiilor viitoare, să nu fie compromise" [5].

Unul dintre cele mai importante argumente pentru conservarea diversității biologice vegetale este faptul că ea prezintă un rezervor enorm de informație genetică utilă pentru programele de îmbunătăţire a culturilor agricole. Cea mai mare parte a populației lumii depinde de un număr foarte restrâns de plante de cultură pentru a-și satisface nevoile nutriționale, iar diversitatea genetică în cadrul acestor culturi se reduce dramatic. 
În contextul menționat o importanță majoră prezintă promovarea activităților de păstrare in situ a diversității genetice din populațiile rudelor sălbatice ale plantelor cultivate (RSPC) [6], precum și în formele autohtone de plante agricole în gospodăriile țărănești - conservarea on farm $[7,8]$. Păstrarea resurselor genetice vegetale pentru alimentaţie și agricultură presupune efectuarea unor măsuri concrete, inclusiv legate de inventarierea și colectarea germoplasmei vegetale. Aceste lucrări au constituie direcțiile de cercetare executate în cadrul Laboratorului Resurse Genetice Vegetale pe parcursul a mai multor ani. În prezenta lucrare sunt expuse doar unele rezultate la acest capitol.

\section{Materiale și metode}

Investigaţiile s-au efectuat în ecosistemele forestiere din toate zonele pedo-climatice ale republicii, localitățile rurale specifice unităților teritorial-administrative, în laborator și sectoarele experimentale. Poziționarea populațiilor de plante studiate în mediul natural și inventarierea gospodăriilor mici țărănești a fost realizată cu GPS-navigatorul Garmin eTrex H. Studiile au inclus determinarea unor indici cantitativi ai culturilor pilot (înălțimii plantelor, diametrului arborilor etc.), rezistenței la factorii stresanți ai mediului. S-a elucidat specificul cultivării diferitelor specii de culturi agricole și s-a colectat material semincer sau săditor.

\section{Rudele sălbatice ale plantelor cultivate.}

\section{Rezultate și discuţii}

RSPC reprezintă un compartiment al agrobiodiversităţii puțin utilizat în republică în calitate de surse de material iniţial pentru ameliorarea culturilor agricole și în alte domenii ale economiei. Pe teritoriul Republicii Moldova sunt înregistrate peste 1820 de specii de plante vasculare, atribuite la 616 genuri şi 136 de familii [6]. Grație poziției geografice republica nu face parte din vreo-un centru primar de origine al plantelor cultivate, însă o serie de specii din diferite ecosisteme naturale corespund criteriilor necesare pentru a fi incluse în categoria RSPC.

Investigațiile noastre s-au efectuat în ecosistemele forestiere din toate zonele pedo-climatice ale țării și au cuprins suprafețele de păduri din cadrul întreprinderilor pentru silvicultură ale Agenției „Moldsilva”, inclusiv și ariile naturale protejate de Stat. Au fost alese 5 specii pilot - mărul pădureț (Malus sylvestris L. Mill.), cireșul sălbatic (Prunus avium L.), alunul (Corylus avellana L.), părul sălbatic european (Pyrus pyraster (L.) Burgsd.) și cornul (Cornus mas L.). Acești arbori și arbuști ocupă diferite nișe ecologice, este diferit și rolul lor în funcționarea comunităților silvice. Cireșul sălbatic se întâlnește, mai ales, în zona centrală şi cea de nord, mai puţin în cea de sud, fiind un element al pădurilor foioase amestecate. În nordul ţării cireşul este situat, de regulă, în plafonul superior cu Quercus robur, în centrul republicii - în gorunete, stejarete din stejar pedunculat, fagete şi şleauri; de rând cu ulmul, plopul tremurător, paltinul de câmp şi paltinul de munte cireşul sălbatic reprezintă un element însoţitor al speciilor edificatoare. Zone neînsemnate se atestă în sudul republicii în arboretele de stejar pedunculat cu porumbar. Părul pădureț este răspândit în pădurile de stejar pedunculat și carpen, de stejar cu tei și frasin în etajul doi al arboretului sau în subarboret. Alunul și cornul sunt prezente în toate zonele naturale, mai frecvent în Codri, pe malurile râurilor Nistru și Prut, în codrii Tigheciului, mai puțin frecvent în regiunile sudice și nordice. Mărul pădureț se semnalează pe tot teritoriul Republicii Moldova, însă mai abundent în zona de nord și centru, de obicei, în populații restrânse sau arbori izolați. Unele date privind răspândirea populațiilor speciilor menționate sunt prezentate în tabel.

În rezultatul evaluărilor efectuate s-a constatat că în anii de studiu populațiile unor specii au degradat mult de pe urma calamităţilor naturale. Astfel, secetele frecvente au provocat uscarea prematură a cireșului (ocoalele silvice Zloți, Hâncești, Nisporeni, Cociulia, Aria protejată Vila Caracui ș.a.), înhibarea dezvoltării și deprimarea fructificării la alun, corn, peirea mărului pădureț.

Trezește îngrijorare faptul depistării în comunitățile silvice a unor genotipuri hibride cu implicarea mărului pădureț și părului sălbatic, fapt alarmant ce pune sub pericol eficacitatea păstrării în siguranță a populațiilor acestor specii. În acelaşi timp, în diferite ocoale silvice au fost semnalate exemplare valoroase, din punct de vedere al productivității și rezistenței, de păr pădureț, cireș sălbatic (ocoalele silvice Strășeni, Nisporeni, Sângerei ș.a.) care necesită a fi monitorizate și utilizate în silvicultură și ameliorare.

Formele locale (varietăţile tradiționale) de culturi agricole. 
Dezvoltarea sistemului agricol în republică în ultimii 60-80 de ani a avut un impact negativ asupra genofondului autohton al plantelor cultivate. Fiind atașate la sistemele traditionale de management agricol practicat de ani de zile în gospodăriile mici țărănești, varietățile locale au suferit dramatic în epocile colectivizării, concentrări și specializării agriculturii, fiind supuse unei eroziuni genetice substanțiale. Multe genotipuri practicate anterior au dispărut, răpândirea altora s-a dovedit a fi foarte limitată, fapt stabilit în urma expedițiilor executate în toate raioanele țării. În gospodăriile ţărăneşti au fost colectate peste 900 de mostre locale de plante cerealiere, leguminoase, legumicole, tehnice, medicinale ce aparţin unui set de peste 40 de specii. S-au înregistrat exemplare de pomi fructiferi (peri, meri) de o vârsta de 80-120 de ani care prezintă interes pentru conservare și ameliorare. Mostrele colectate au fost evaluate ex situ și au completat colecțiile respective pentru conservare în Banca de gene.

Tabel.Unele site-uri de răspândire ale speciilor pilot în ecosistemele forestiere

\begin{tabular}{|c|c|c|c|c|c|c|}
\hline \multirow[t]{2}{*}{ Site-ul } & \multirow{2}{*}{$\begin{array}{c}\text { Data } \\
\text { evaluării }\end{array}$} & \multirow[t]{2}{*}{$\mathrm{D}$} & \multirow[t]{2}{*}{ ÎA } & \multirow[t]{2}{*}{ NA } & \multicolumn{2}{|c|}{ Localizarea } \\
\hline & & & & & Nord & Est \\
\hline \multicolumn{7}{|c|}{ Prunus avium } \\
\hline O.S.Criuleni & 04.08 .2011 & $29-33$ & $12-17$ & 25 & $47^{\circ} 10^{\prime} 79^{\prime \prime}$ & $28^{\circ} 59^{\prime} 76^{\prime \prime}$ \\
\hline O.S.Pohrebeni & 24.09 .2020 & $10-20$ & $8-12$ & 10 & $47^{\circ} 33^{\prime} 22^{\prime \prime}$ & $28^{\circ} 53^{\prime} 67^{\prime \prime}$ \\
\hline R.Ș.Plaiul Fagului & 28.10 .2009 & $36-60$ & $18-20$ & 15 & $47^{\circ} 17^{\prime} 83^{\prime \prime}$ & $28^{\circ} 01^{\prime} 34^{\prime \prime}$ \\
\hline O.S. Nisporeni & 30.09 .2011 & 10 & $9-10$ & 40 & $47^{\circ} 00^{\prime} 36^{\prime \prime}$ & $28^{\circ} 14^{\prime} 95^{\prime \prime}$ \\
\hline O.S.Vatici & 25.09 .2020 & 47 & 20 & 41 & $47^{\circ} 20^{\prime} 28^{\prime \prime}$ & $28^{\circ} 36^{\prime} 35^{\prime \prime}$ \\
\hline O.S. Bobeică & 27.09 .2011 & $10-28$ & $10-17$ & 16 & $46^{\circ} 55^{\prime} 46^{\prime \prime}$ & $28^{\circ} 33^{\prime} 85^{\prime \prime}$ \\
\hline \multicolumn{7}{|c|}{ Pyrus pyraster } \\
\hline O.S.Florești & 08.10 .2015 & $90-110$ & $13-20$ & 17 & $48^{\circ} 00^{\prime} 16^{\prime \prime}$ & $28^{\circ} 00^{\prime} 90^{\prime \prime}$ \\
\hline O.S.Criuleni & 04.08 .2011 & $23-30$ & $13-15$ & 6 & $47^{\circ} 10^{\prime} 51^{\prime \prime}$ & $28^{\circ} 59^{\prime} 96^{\prime \prime}$ \\
\hline O.S.Pohrebeni & 24.09 .2020 & 30 & 12 & 1 & $47^{\circ} 32^{\prime} 63^{\prime \prime}$ & $29^{\circ} 53^{\prime} 78^{\prime \prime}$ \\
\hline O.S.Bobeică & 27.09 .2011 & $20-28$ & $10-12$ & 4 & $46^{\circ} 56^{\prime} 30^{\prime \prime}$ & $28^{\circ} 33^{\prime} 22^{\prime \prime}$ \\
\hline O.S.Soroca & 07.10 .2015 & $22-73$ & $10-15$ & 2 & $48^{\circ} 09^{\prime} 15^{\prime \prime}$ & $28^{\circ} 12^{\prime} 90^{\prime \prime}$ \\
\hline O.S.Ciorești & 23.10 .2020 & 15 & 8 & 2 & $47^{\circ} 10^{\prime} 25^{\prime \prime}$ & $28^{\circ} 10^{\prime} 41^{\prime \prime}$ \\
\hline \multicolumn{7}{|c|}{ Cornus mas } \\
\hline O.S.Vatici & 25.09 .2020 & $4-5$ & $4-8$ & 57 & $47^{\circ} 18^{\prime} 29^{\prime \prime}$ & $28^{\circ} 36^{\prime} 11^{\prime \prime}$ \\
\hline O.S. Hîrbovăț & 28.05 .2009 & $1,5-3$ & $2-3$ & 21 & $46^{\circ} 51^{\prime} 97^{\prime \prime}$ & $29^{\circ} 23^{\prime} 81^{\prime \prime}$ \\
\hline O.S. Măndrești & 26.08 .2008 & 3 & 3 & 6 & $47^{\circ} 28^{\prime} 40^{\prime \prime}$ & $28^{\circ} 15^{\prime} 68^{\prime \prime}$ \\
\hline R.Ș. Plaiul Fagului & 30.09 .2014 & $5-10$ & $4-6$ & 3 & $47^{\circ} 18^{\prime} 85^{\prime \prime}$ & $28^{\circ} 05^{\prime} 64^{\prime \prime}$ \\
\hline O.S.Telenești & 26.08 .2008 & 5 & 6 & 38 & $47^{\circ} 27^{\prime} 91^{\prime \prime}$ & $28^{\circ} 29^{\prime} 47^{\prime \prime}$ \\
\hline O.S.Ocnița & 24.08 .2007 & $3-6$ & $3-4$ & 2 & $48^{\circ} 26^{\prime} 47^{\prime \prime}$ & $27^{\circ} 35^{\prime} 86^{\prime \prime}$ \\
\hline \multicolumn{7}{|c|}{ Malus sylvestris } \\
\hline O.S.Zloți & 16.08 .2013 & 28 & 10 & 1 & $46^{\circ} 40^{\prime} 93^{\prime \prime}$ & $28^{\circ} 54^{\prime} 67^{\prime \prime}$ \\
\hline O.S.Telenești & 26.98 .2008 & 24 & 11 & 2 & $47^{\circ} 29^{\prime} 24^{\prime \prime}$ & $28^{\circ} 23^{\prime} 33^{\prime \prime}$ \\
\hline O.S.Pohrebeni & 24.09 .2020 & 28 & 15 & 1 & $47^{\circ} 31^{\prime} 84^{\prime \prime}$ & $28^{\circ} 54^{\prime} 31^{\prime \prime}$ \\
\hline O.S.Strășeni & 05.08 .2011 & 16 & 13 & 1 & $47^{\circ} 05^{\prime} 54^{\prime \prime}$ & $28^{\circ} 34^{\prime} 54^{\prime \prime}$ \\
\hline R.Ș. Codrii & 10.07 .2008 & 36 & 6 & 1 & $47^{\circ} 06^{\prime} 42^{\prime \prime}$ & $28^{\circ} 21^{\prime} 66^{\prime \prime}$ \\
\hline OS Sângerei & 27.06 .2012 & 13 & 5 & 1 & $47^{\circ} 36^{\prime} 03^{\prime \prime}$ & $28^{\circ} 08^{\prime} 61^{\prime \prime}$ \\
\hline \multicolumn{7}{|c|}{ Corylus avellana } \\
\hline O.S.Scoreni & 28.0820 .08 & $2-4$ & $2-3$ & 20 & $47^{\circ} 05^{\prime} 49^{\prime \prime}$ & $28^{\circ} 33^{\prime} 74^{\prime \prime}$ \\
\hline R.Ș. Plaiul Fagului & 28.10 .2009 & $1-15$ & $6-8$ & 10 & $47^{\circ} 17^{\prime} 76^{\prime \prime}$ & $28^{\circ} 10^{\prime} 35^{\prime \prime}$ \\
\hline O.S.Ciorești & 23.10 .2020 & $1-10$ & 4 & 2 & $47^{\circ} 09^{\prime} 58^{\prime \prime}$ & $28^{\circ} 33^{\prime} 74^{\prime \prime}$ \\
\hline O.S.Telenești & 26.08 .2008 & $2-8$ & $3-4$ & 12 & $47^{\circ} 29^{\prime} 24^{\prime \prime}$ & $28^{\circ} 29^{\prime} 32^{\prime \prime}$ \\
\hline O.S.Vatici & 25.09 .2020 & $2-4$ & $2-3$ & 2 & 4719’39" & $28^{\circ} 35^{\prime} 52^{\prime \prime}$ \\
\hline O.S.Cimişlia & 15.08 .2013 & $5-8$ & $3-4$ & 38 & $46^{\circ} 30^{\prime} 48^{\prime \prime}$ & $28^{\circ} 45^{\prime} 28^{\prime \prime}$ \\
\hline
\end{tabular}

O.S. - ocolul silvic; Î.S. - întreprinderea pentru silvicultură; R.Ș. - rezervația științifică; D-diametrul tulpinii, cm; ÎA - Înălțimea arborelui/arbustului, m; NA- Numărul de arbori/arbuști. 


\section{Concluzii}

1. A fost efectuată inventarierea și evaluarea populațiilor de măr pădureț, alun, cireș sălbatic, păr pădureț și corn în ecosistemele forestiere din diferite zone pedo-climatice ale republicii.

2. S-a executat poziționarea gospodăriilor țărănești și s-au colectat forme autohtone de culturi agricole pentru evaluarea lor ulterioară și conservarea ex situ.

3. A fost depistat faptul degradării populațiilor speciilor pilot din cauza calamităților naturale frecvente și practicării unor activități silvotehnice neadecvate. S-a constatat faptul dispariției multor soiuri autohtone valoroase de plante cultivate.

4. Evidențierea prezenței în comunitățile forestiere a unor forme hibride între mărul pădureț, părul pădureț și genotipurile de cultură cere implementarea unor măsuri urgente de conservare garantată in situ a rudelor sălbatice ale plantelor cultivate.

Cercetările au fost realizate în cadrul proiectului institutional 15.817.05.15A „Elaborarea și managementul Sistemului naţional de conservare a agrobiodiversității vegetale pentru agricultură și securitatea alimentară a Republicii Moldova", precum și a Programului de Stat 20.80009.5107.11 "Conservarea ex situ de lungă durată a resurselor genetice vegetale în Banca de gene cu utilizarea metodelor biologiei moleculare în testarea stării de sănătate a germoplasmei vegetale", finanțat de Agenția Națională pentru Cercetare și Dezvoltare.

\section{Bibliografie}

1. Resolution 70/1 adopted by the General Assembly UN on 25 September 2015. Transforming our world: the 2030 Agenda for Sustainable Development. New York, 2015, 35 p.

2. Nature Risk Rising: Why the Crisis Engulfing Nature Matters for Business and the Economy. World Economic Forum. Geneva, Switzerland, 2020, 34 p.

3. Intergovernmental Science-Policy Platform on Biodiversity and Ecosystem Services (IPBES). Media Release: Nature's Dangerous Decline 'Unprecedented'; Species Extinction Rates 'Accelerating'. https://ipbes.net/news/Media-Release-Global-Assessment

4. FRISON, E.A.; CHERFAS, J.; HODGKIN, T. Agricultural biodiversity is essential for a sustainable improvement in food and nutrition security. 2011. Sustainability 3(12), pp.238-253.

5. High Level Panel of Experts on Food Security and Nutrition of the Committee on World Food Security of the FAO. Food Losses and Waste in the Context of Sustainable Food Systems. Extract from the Report. Rome: FAO. 2014. 9 p.

6. HEYWOOD, V.H.; DULLOO, M.E. In situ conservation of wild plant species: a critical global review of best practices. IPGRI Technical Bulletin 11. IPGRI, Rome, Italy, 2005, $174 \mathrm{p}$.

7. MAXTED, N.; GUARINO, L.; MYER, L.; CHIWONA, E.A. Towards a methodology for on-farm conservation of plant genetic resources. Genetic Resources and Crop Evolution, 2002, 49(1), pp.31-46.

8. JARVIS, D.I.; MYER, L.; KLEMICK, H.; GUARINO, L., et al. A Training Guide for In Situ Conservation Onfarm. Version 1. IPGRI, Rome, Italy, 2000, $161 \mathrm{p}$.

9. NEGRU, A. Determinator de plante din flora Republicii Moldova. Chișinău, 2007, 391 p. 